\title{
The Model of Water Temperature Change in the Bathtub
}

\author{
Siyu Zhu \\ School of Electric Power Engineering, North China Electric Power University, Baoding 071003, \\ China \\ zhusiyu2017@163.com
}

Keywords: water temperature change, thermology, endothermic process, exothermic process, Runge-Kutta method

\begin{abstract}
This paper describes model testing of bathtub with the purpose of remaining the water temperature in the bathtub constant and reducing water waste. I establish a model and draw a conclusion. The model describes changes in the temperature of the bathtub water.

The model has two parts: the one is endothermic process that a constant trickle of hot water reheats the bathing water and the other one is exothermic process. The exothermic process is divided into three parts: on the water surface, on the bathtub wall and between bathtub bottom and ground. Finally, I get a formula about the temperature of the water according to the theory of thermology. I find that it is effective for bubble bath additive to help to keep the temperature constant in the extended model I carry out numerical calculation by using Runge-Kutta method and compare analytic and numerical results with reality, using default parameters; I validate that my method is correct and robust.
\end{abstract}

\section{Introduction}

As shown in Fig. 1, the exothermic process is divided into three parts, and this process on the water surface is also divided into three parts: evaporation, thermal radiation and heat convection. [1] And the other two positions only contain heat conduction.

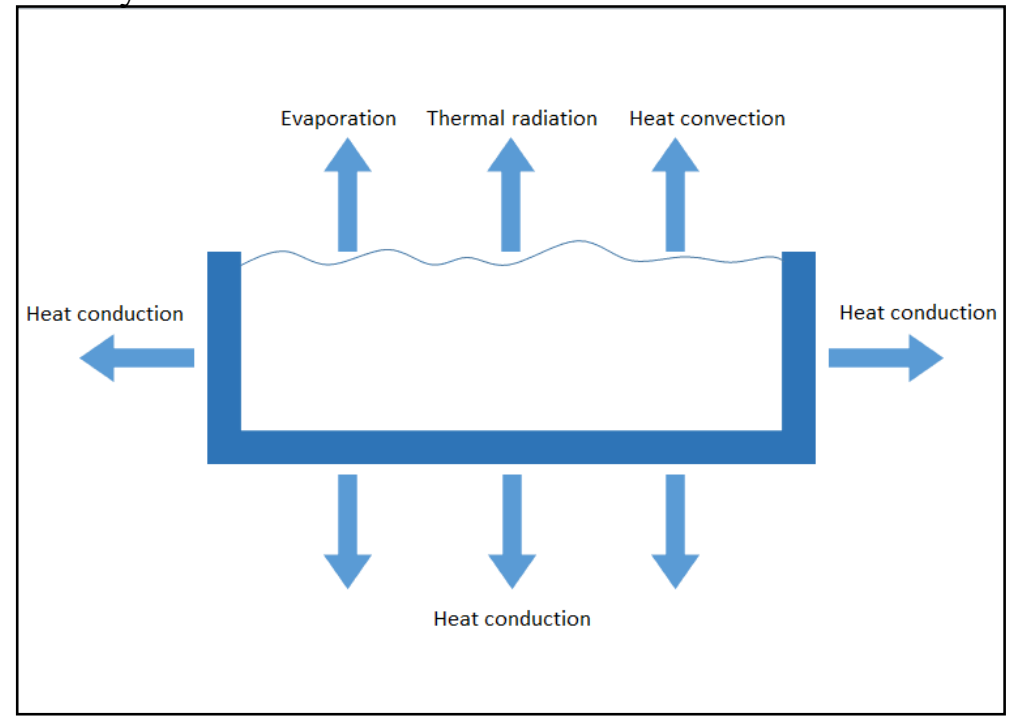

Fig. 1: Exothermic Process

Modern medicine indicates that the best temperature for bathing is between 37 and 40 . So I suppose the initial temperature is 37 and the temperature of the bathtub water remains in this range.

The heat process is divided into two parts: the one is endothermic process that the constant trickle of hot water reheats the bathing water and the other one is exothermic process.

First, I calculate heat absorption of the endothermic process by calculating the heat contained in the hot water. Then, I calculate heat dissipation through the exothermic process. Next, I calculate the change of the temperature of the bathtub water by calculating the difference between the heat absorption and the heat dissipation. Then, I try and reduce them to formula.

Finally, I differentiate the formula and get the model of the temperature of the bathtub water in time. 


\section{The model}

Table 1: Parameter

\begin{tabular}{|c|c|c|}
\hline Parameter & Meaning & Unit \\
\hline$F$ & Contact area between water and air & $\mathrm{m}^{2}$ \\
\hline$S_{s}$ & Area of the wall of the bathtub & $\mathrm{m}^{2}$ \\
\hline$S_{u}$ & Area of the bathtub bottom & $\mathrm{m}^{2}$ \\
\hline$T$ & The water temperature & K \\
\hline$M_{0}$ & Bathtub water's mass & $\mathrm{kg}$ \\
\hline$m$ & $\begin{array}{l}\text { The mass flow rate of the constant trickle } \\
\text { of hot water }\end{array}$ & $\mathrm{Kg} / \mathrm{s}$ \\
\hline$\theta$ & Dry bulb temperature of the air & $\mathrm{K}$ \\
\hline$\beta$ & Evaporation coefficient & $\mathrm{W} /\left(\mathrm{m}^{2} \cdot \mathrm{hPa}\right)$ \\
\hline$\alpha$ & Convective heat transfer coefficient & $\mathrm{W} /\left(\mathrm{m}^{2} \cdot \mathrm{K}\right)$ \\
\hline W & Air speed above the water's surface & $\mathrm{m} / \mathrm{s}$ \\
\hline$h$ & Thermal conductivity of the bathtub & $\mathrm{W} /\left(\mathrm{m}^{2} \cdot \mathrm{K}\right)$ \\
\hline$p_{v}$ & $\begin{array}{l}\text { Steam pressure of thin saturated layer of } \\
\text { water surface }\end{array}$ & $\mathrm{hPa}$ \\
\hline$p_{v}$ & partial pressure of the wet air & $\mathrm{hPa}$ \\
\hline$k$ & thermal accommodation coefficient & $\mathrm{W} /\left(\mathrm{m}^{2} \cdot \mathrm{K}\right)$ \\
\hline$T_{0}$ & Constant current hot water temperature & $\mathrm{K}$ \\
\hline C & The specific heat of the hot water & $\mathrm{J} /(\mathrm{kg} \cdot \mathrm{K})$ \\
\hline$Q_{a}$ & $\begin{array}{l}\text { The heat transferred from water surface } \\
\text { to air per second due to heat convection. }\end{array}$ & W \\
\hline$Q_{b}$ & $\begin{array}{l}\text { The heat transferred from water surface } \\
\text { to air per second due to evaporation. }\end{array}$ & W \\
\hline$Q_{c}$ & $\begin{array}{l}\text { The heat transferred from water surface } \\
\text { to air per second due to thermal radiation. }\end{array}$ & W \\
\hline$Q_{d}$ & $\begin{array}{l}\text { The heat transferred from the bathtub } \\
\text { wall to air per second due to heat } \\
\text { conduction. }\end{array}$ & W \\
\hline$Q_{e}$ & $\begin{array}{l}\text { The heat transferred from the bathtub } \\
\text { bottom to ground per second due to heat } \\
\text { conduction. }\end{array}$ & $\mathrm{W}$ \\
\hline$Q_{f}$ & $\begin{array}{l}\text { The heat transferred from the constant } \\
\text { trickle of hot water from the faucet to the } \\
\text { bathtub water per second }\end{array}$ & $\mathrm{W}$ \\
\hline $\begin{array}{l}Q \\
\varepsilon \sigma\end{array}$ & $\begin{array}{l}\text { The heat of the bathtub water per second } \\
\text { Radiance }\end{array}$ & W \\
\hline
\end{tabular}

Step1.Endothermic Process:I need to supplement the loss of the water's temperature by adding water from the water tap. So I get a formula like this:

$$
Q_{f}=c\left(T_{0}-T\right) m \text {, }
$$

Step2.Exothermic Process: As mentioned above, the exothermic process is divided into three parts, and this process on the water surface is also divided into three parts: evaporation, thermal radiation and heat convection.

The heat that the bathtub water loses by heat convection can be represented as:

$$
Q_{a}=\alpha(T-\theta) F
$$

The heat that the bathtub water loses by evaporation can be represented as:

$$
Q_{b}=\beta\left(p_{v}{ }^{\prime \prime}-p_{v}\right) F
$$

According to literature[1] The evaporation coefficient (" $\beta$ ") can be represented as:

$$
\beta=\left[22.0+12.5 W^{2}+2.0(T-\theta)\right]^{2}
$$

The heat that the bathtub water loses by thermal radiation can be represented as:

$$
Q_{c}=\varepsilon \sigma T^{4} F
$$

The heat that the bathtub water loses by heat conduction on the bathtub wall can be represented as: 


$$
Q_{d}=h(T-\theta) S_{s}
$$

The heat that the bathtub water loses by heat conduction between the bathtub bottom and ground can be represented as:

$$
Q_{e}=k(T-\theta) S_{u}
$$

Step3.Energy Analysis: For the bathtub water, its heat change process is related to the change of the temperature of it. So I get an expression like this:

$$
Q=Q_{a}+Q_{b}+Q_{c}+Q_{d}+Q_{e}-Q_{f} .
$$

If I want to keep the temperature constant, I should make $Q=0$.

\section{Numerical Computation}

The coefficient of convective heat transference between water and air is generally 5-200. Thus, I generally assume $\alpha=100$.

According to modern medical research, the most suitable indoor temperature of human habitation is 25 , so I assume dry bulb temperature $(\theta)$ of the air is 25 that Kelvin temperature is $298 \mathrm{~K}$.

Because I assume that the bathtub is placed in a small, enclosed room, so I assume that the air speed $(W)$ is 0.1 .

According to the reference, I assume $\varepsilon \sigma=0.97, p_{v}{ }^{\prime \prime}=42 \mathrm{hPa}$ and $p_{v}=33.6 \mathrm{hPa}$.

Because most of the bathtub material is acrylic, so I assume $h=k=0.19$.

I know that the size of the majority of bathtub is $1.7 * 0.8 * 0.7$ by asking bathtub companies. I assume that $m_{0}$ (which represents the mass of the water in the bathtub after the person is lying in the bathtub) $=230 \mathrm{~kg}$. And I conservatively assume that $S_{s}=3.5 \mathrm{~m}^{2}, \mathrm{~F}=1.5 \mathrm{~m}^{2}$ and $S_{u}=1.36 \mathrm{~m}^{2}$.

As I assumed, $T_{0}=333 \mathrm{~K}$.

Numerical calculation was carried out by using Runge-Kutta method, and Fig. 2 shows the output figure from numerical simulation.

As Fig. 2(a) shows, only considering the heat dissipation process, the relationship between the temperature and time is a smooth concave curve. And I see that the temperature decreases by $3 \mathrm{~K}$ for about 1000 seconds.

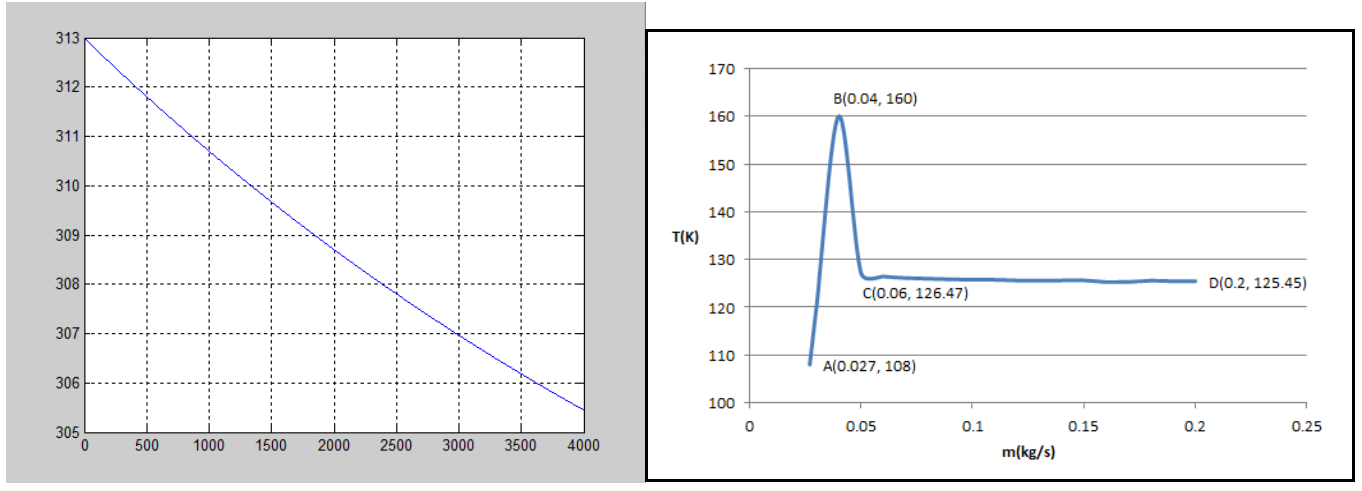

(a)

(b)

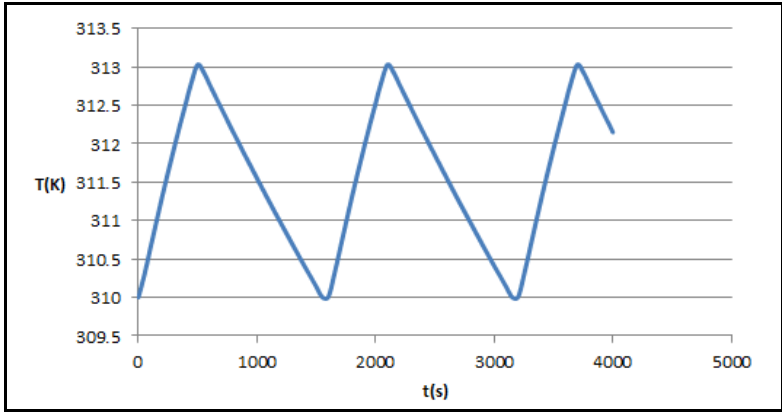

(c)

Fig.2: (a): The relationship between the temperature and time about the heat dissipation process.

(b): The relationship between $m$ and $M$.

(c): The relationship between time and temperature if people add water intermittently. 
As Fig. 2(b) shows, I can get the relationship between $m$ and $M$. The curve between A and B describes the relationship between $m$ and $M$ when people add water constantly, and the curve between $\mathrm{C}$ and D describes the relationship between $m$ and $M$ when people add water intermittently. As Fig. 2(b) shows, $M$ is proportional tom when people add water constantly, and if the temperature keeps at $309.5 \mathrm{~K}$, the total water injection is minimized. In addition, $M$ is inversely proportional tom when people add water intermittently, and $m$ should range from $0.06 \mathrm{~kg} / \mathrm{s}$ to $0.2 \mathrm{~kg} / \mathrm{s}$ to make water consumption minimal.

As Fig. 2(c) shows, if people add water intermittently, he should run the faucet periodically, and the time of the cycle is 1550s.

As Fig. 3 shows, if the temperature of the constant hot water changes, the total water injection will also changes and the total water injection will reduce when the temperature of the constant hot water increases.

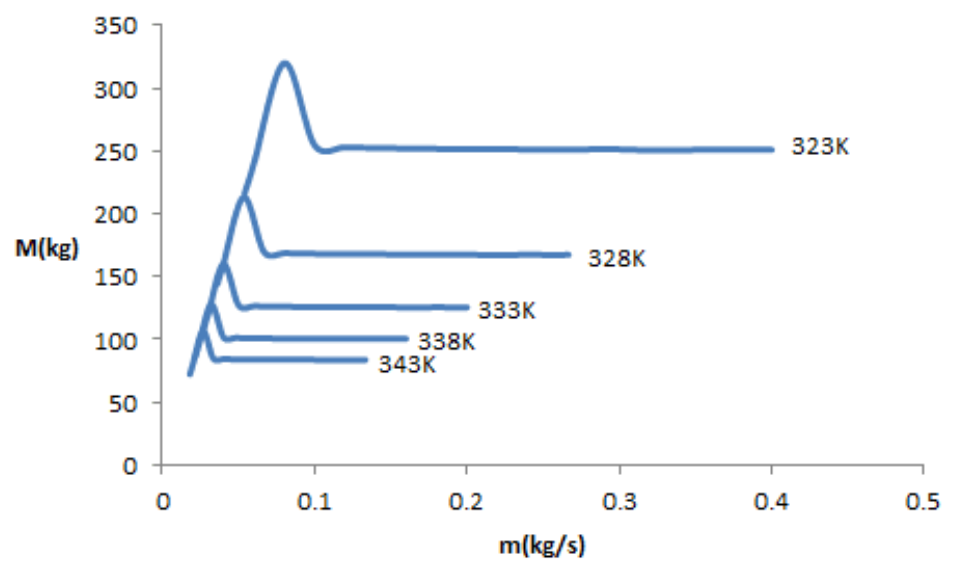

Fig. 3: The relationship between $m$ and $M$ under different temperature.

\section{Conclusions}

The total heat of water will be affected by many complex factors in reality. By and large, the water of the bathtub distributes heat in three ways:

The water distributes heat through the bath, but this process would be affected by the bath materials and the actual room temperature.

The water lose heat by evaporation,in fact, the amount of evaporation will change with the increase of air humidity in the bathroom.

Water has radiation effect, but air has a thermal radiation effect on water, too.

If people want to add the hot water constantly, the total water injection is minimized when the mass flow rate of the constant trickle of hot water is $0.027 \mathrm{~kg} / \mathrm{s}$.

If people want to add water intermittently, the total water injection is minimized when the mass flow rate of the constant trickle of hot water ranges from $0.06 \mathrm{~kg} / \mathrm{s}$ to $0.2 \mathrm{~kg} / \mathrm{s}$. In addition, people should switch the faucet 1550 seconds.

According to my model, the more heat you add, the more water you can save. But in order to prevent hot water scald you, I recommend that you can use a higher temperature of water without burning your case.

\section{References}

[1]Zhenguo Zhao. 2004.Enthalpy difference formula for calculating heat dissipation on watersurface and its use.Journal of Hydraulic Engineering, 2004.

[2]Huiquan Chen, Shimin Mao.1991.Water surface evaporation and heat dissipation coefficient research - national general formula (B) [R].Cooperation Group on water surface evaporation and heat dissipation coefficient, 1991. 
[3]Minghui Wang. 1992. Temperature and humidity should be kept in the room.Primary health care in China, 1992.

[4]Zhigang Cheng, Hongxia Li. 2013.Research on heat transfer between objects and its practical application.ChengShi Jianshe LiLun Yan Jiu, 2013.

[5]Shiming Yang.2006.heat transfer theory.Higher Education Press,2006. 